\title{
Observations suggesting bioactive Fgf15 is not present in mouse blood
}

I read with interest the paper by Uriarte et $a l,{ }^{1}$ in which the authors conclude that 'Fgf15 is a key mediator of the liver growth-promoting effects of bile acids.'

There are reasons to question the conclusions drawn in this paper. Due to space limit I forward three issues.

(1) Fgf15 exerts its effects via FGFR4 as mentioned. The authors have not recognised a report by $\mathrm{Yu} e t a l^{2}$ showing that deletion of FGFR4 does not alter the ability of the liver to regenerate after partial hepatectomy.

How can circulating Fgf15 (derived from the gut as currently often believed, and as also these authors claim) be crucial for liver regeneration, when FGFR4 has no role in liver regeneration ${ }^{2}$ ?

This discrepancy strongly suggests that the inability of the liver to regenerate in Fgf15KO mice is independent of FGFR4, and by consequence, must be explained by FGFR4-independent actions.

This, in turn, implies that changes in any circulating Fgf15 from gut to liver is highly unlikely to explain why liver regeneration in FGF15KO mice is impaired, provided that FGFR4 indeed is the receptor for Fgf15. One plausible explanation for this intriguing latter conclusion is that Fgf15 is simply not present in mouse or rat blood plasma, which is actually in line with previous and recent $^{3}$ failures to detect Fgf15 in rodent plasma. It must be remembered that the evidence for the presence of circulating Fgf15 are circumstantial, and that an alternative mechanism explaining 'Fgf15-caused' effects on bile acid synthesis was recently suggested ${ }^{4}$ that is soon to be demonstrated.

(2) In the introduction, the authors state that: 'After reaching the liver through the portal circulation, Fgf15 was shown to bind and activate the FGF receptor 4 (FGFR4)'.

This statement is incorrect. The evidence for circulating Fgf15 are circumstantial, and the presence of circulating Fgf15 has never been shown, as mentioned presumably because it is not there. If authors have data on mouse plasma Fgf15, please indicate that.

(3) Authors show that incubation of mouse hepatocytes with 50 and $100 \mathrm{ng} / \mathrm{ml}$ of FGF19 stimulates cell proliferation. In normal human plasma FGF19 averages 
$0.146 \mathrm{ng} / \mathrm{ml}^{4}{ }^{4}$ The doses employed are thus 350-700 times higher than that. What was the rationale for such doses? With such suprapharmacological FGF19 doses on mouse cells, virtually anything could happen, please see ref. ${ }^{5}$ for this serious matter.

\section{Mats Rudling}

Correspondence to Professor Mats Rudling, Metabolism Unit, Center for Endocrinology, Metabolism, and Diabetes, Karolinska Institute, C2-94, Karolinska University Hospital Huddinge, Stockholm S-141 86, Sweden; mats.rudling@ki.se

\section{Competing interests None.}

Provenance and peer review Not commissioned; internally peer reviewed.

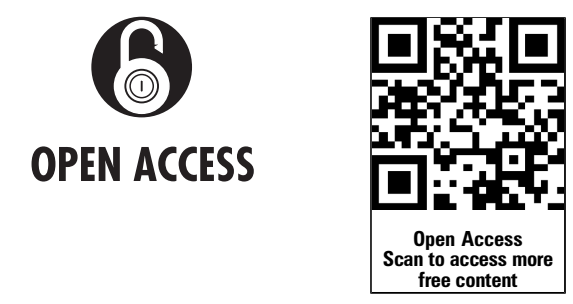

Open Access This is an Open Access article distributed in accordance with the Creative Commons Attribution Non Commercial (CC BY-NC 3.0) license, which permits others to distribute, remix, adapt, build upon this work non-commercially, and license their derivative works on different terms, provided the original work is properly cited and the use is noncommercial. See: http://creativecommons.org/licenses/ by-nc/3.0/

To cite Rudling M. Gut 2014;63:205-206.

Received 5 May 2013

Revised 7 May 2013

Accepted 8 May 2013

Published Online First 8 June 2013

\section{(5) Linked}

- http://dx.doi.org/10.1136/gutjnl-2012-302945

- http://dx.doi.org/10.1136/gutjnl-2013-305251

Gut 2014;63:205-206.

doi:10.1136/gutjnl-2013-305227

\section{REFERENCES}

1 Uriarte I, Fernandez-Barrena MG, Monte MJ, et al. Identification of fibroblast growth factor 15 as a novel mediator of liver regeneration and its application in the prevention of post-resection liver failure in mice. Gut 2013;62:899-910.

2 Yu C, Wang F, Kan M, et al. Elevated cholesterol metabolism and bile acid synthesis in mice lacking membrane tyrosine kinase receptor FGFR4. J Biol Chem 2000;275:15482-9.

3 Montagnani $\mathrm{M}$, Tsivian $\mathrm{M}$, Neri $\mathrm{F}$, et al. A new model for portal protein profile analysis in course of ileal intraluminal bile acid infusion using an in situ perfused rat intestine. Med Chem 2011;7:257-64.
4 Angelin B, Larsson TE, Rudling M. Circulating fibroblast growth factors as metabolic regulators-a critical appraisal. Cell Metab 2012;16:693-705.

5 Nakamura M, Uehara Y, Asada M, et al. Sulfated glycosaminoglycan- assisted receptor specificity of human fibroblast growth factor (FGF) 19 signaling in a mouse system is different from that in a human system. J Biomol Screen 2013;18:321-30. 